\author{
Анатолій Ірза, \\ аспірант 1 курсу навчання \\ кафедри психологї Львівського \\ Національного університету \\ імені Івана Франка
}

E-mail: anatOly@bigmir.net

Anatoliy Irza,

postgraduate student

of the 1st course Department

of Psychology of Lviv National Ivan

Franko University

\title{
ПОНЯТТЯ СОЩАЛЬНО-ПСИХОЛОГІЧНОЇ ЗРІЛОСТІ ОСОБИСТОСТІ: АНАЛІЗ ЗАКОРДОННИХ ТА ПЕРСПЕКТИВИ СУЧАСНИХ ВІТЧИЗНЯНИХ ДОСЛІДЖЕНЬ
}

\begin{abstract}
Проаналізовано сочіально-психологічну зрілість як багатовимірну систему виховання, що є якісною характеристикою людини та покликана забезпечити иілеспрямований процес самореалізації, саморозвитку, встановлення гармонійних відносин між людиною і світом тощо. Виявлено, щуо основні складові соціально-психологічної зрілості залишаються мало дослідженими. Розглянуто значущість розроблення у психології інтегрального поняття «сочіально-психологічна зрілість». Проаналізовано розуміння поняття соціально-психологічної зрілості у закордонній психологічній науці. Акцентовано увагу на відмінностях у розумінні науковцями поняття соціально-психологічної зрілості, ї̈ структурних компонентів. Розглянуто розроблення поняття соціально-психологічної зрілості як складного інтегрального феномену, який обумовлює взаємодію людини та суспільства, пояснює взаємини з іншими людьми, особливості вчинкової природи людини. Висвітлено особливості «набуття» соціальнопсихологічної зрілості у повсякденному житті через зміни структурних компонентів. Визначено основні проблемні аспекти перебігу, набуття та вияву соціально-психологічної зрілості для ліпшого розуміння зон найближчого розвитку особистості, а також можливих напрямків досліджень. Досліджено компоненти соціально-психологічної зрілості та їх складну динамічну особистісну структуру, щуо проявляється у чотирьох визначених сферах. Узагальнено основні історичні етапи формування поняття сочіально-психологічної зрілості, бачення концепції у відповідних історичних періодах. Проаналізовано історичні кризи інтерпретації терміну зрілості. У висновку подано більш узгоджене бачення феномена сочіально-психологічної зрілості в сучасних вітчизняних і зарубіжних розвідках дослідників.
\end{abstract}

Ключові слова: індивід, особистість, суспільство, зрілість, біологічна зрілість, соиіальна зрілість, психологічна зрілість, сочіально-психологічна зрілість.

Socio-psychological maturity as a multidimensional system education is a qualitative characteristic of a person and is intended to provide a purposeful process of self-realization, selfdevelopment, establishment of harmonious relations between man and the world and others. Despite such an important importance, the main components of socio-psychological maturity remain little investigated. In this connection, we consider the significance of the development of the integral concept of "socio-psychological maturity" in psychology. An understanding of the concept of socialpsychological maturity in foreign psychological science is analyzed. The attention is paid to the differences in the understanding of the concept of social-psychological maturity, its structural components. The development of the concept of socio-psychological maturity as a complex integral phenomenon, which determines the interaction of man and society, explains the relationship with other people, especially the human nature of nature. Importance is given to highlighting the peculiarities of "acquiring" socio-psychological maturity in everyday life. due to changes in structural components. The main problem aspects of the course, acquisition and manifestation of social-psychological maturity for the better understanding of the zones of the nearest development of the personality, as well as possible directions of research are determined. Generalized the main historical stages of the formation of the concept of social-psychological maturity, vision of the concept in the relevant historical periods. The historical crises of the interpretation of the term maturity are analyzed. There are few consequences for 


\section{Psychology}

the research of the future. The work allowed to collect the disparate data and build a more coherent vision of the phenomenon of socio-psychological maturity in modern domestic and foreign researchers.

Keywords: individual, personality, society, maturity, biological maturity, social maturity, psychological maturity, social and psychological maturity.

Постановка проблеми. Важливим наріжним каменем побудови соціуму є толерантна та доброзичлива взаємодія людей між собою. Соціум також потребує залучення до взаємодії активних громадян, які мають здатність приймати інноваційні рішення, є відповідальними за власну позицію та демократичний розвиток суспільства. Соціально-психологічна зрілість особистості $€$ однією із вагомих психологічних складових відповідальності, емпатійності, позитивних та розвивальних взаємостосунків між людьми. Так, низка авторів (Е. Грінбергер, Б. Спенсер, Б. Соренсен) зазначає, що якість перебігу взаємодії залежатиме від того, наскільки комунікатори набули соціальних навичок та виявляють соціально-психологічну зрілість для їхнього застосування на практиці. Відтак для більш цілісного розуміння сучасної людини та соціуму як життєво взаємозалучених структур виникає необхідність обгрунтування поняття «соціально-психологічної зрілості» особистості.

Поняття вперше було ініційоване дослідженнями Р. Зелмана в 1970 p., на якого вплинули ідеї Дж. Міда. Згідно 3 дослідженнями Р. Зелмана, соціально-психологічну зрілість доречно розглядати як розвиток у людини емпатії, здатності до рефлексії, децентрації, що забезпечить уміння спостерігати за собою збоку. На вітчизняних теренах психологічної науки чітко спостерігається недостатність емпіричних досліджень та теоретичного розроблення поняття соціально-психологічної зрілості. Також відсутньою $є$ всеохоплююча теоретична модель інтегрального поняття, яка може задовольнити найповніше його пояснення. Виникає потреба у розробленні поняття соціальнопсихологічної зрілості як інтегрального поняття. Важливість нового осмислення поняття 3 розумінням сучасних змін соціального та індивідуально-психологічного життя людини дозволить ліпше зрозуміти процеси, що відбуваються у суспільстві, підвищити ефективність взаємодії людини з іншими.

Аналіз останніх досліджень $\boldsymbol{i}$ публікацій. У науці активно розроблялося поняття «зрілості особистості», яке досить активно трансформувалося впродовж усього XX ст. Особистісна зрілість вважається однією 3 соціально позитивних і значущих характеристик людини [Шmеna, 2008: c. 7]. 3 другої половини XX ст. поняття набуває щобільшого соціального та психологічного забарвлення. Вагомий внесок у нове його розуміння внесли закордонні дослідники (Е. Грінбергер, М. Кхатібі， Б. Спенсер， Б. Соренсен， Р. Зелман, Д. Мід, Д. Магнусон, К. Уайт, Д. Марсія, А. Ватерман та ін.). З'являються перші спроби створити нове інтегральне поняття, що буде найбільш широко 


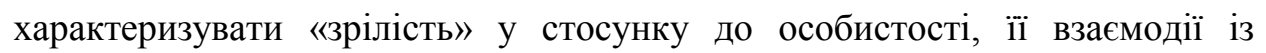
зовнішнім світом. Одна 3 перших моделей соціально-психологічного розвитку була створена у 1974 р. Е. Грінбергером і Б. Соренсеном [Khatibi, 2016: c. 57]. Ця модель окреслювала психосоціальний розвиток студентів та інтегрувала цілі соціалізації (суспільна корисність) та мету розвитку людини (атрибути оптимального особистісного зростання). Це дозволяло моделі охоплювати пояснення діяльності соціуму й окремої людини.

Сучасні дослідники (Н. Леонов, М. Главатських, А. Журавльов, Р. Погорова) у своєму трактуванні поняття «зрілості» продовжили розгляд поняття в контексті традиції досліджень радянського періоду розвитку психології (В. Виготський, І. Кон, О. Ананьєв та ін.). Цей розгляд часто містить доволі некритичне цитування, невідповідність обраному дослідником теоретико-емпіричному підходу. Однак розгляд поняття «зрілості» авторами (А. Ватерманом, А. Журавльовим, О. Тетухіною, А. Лідерсом, О. Чуйко, О. Штепою та ін.) набуває компліментарного підходу і ця тенденція загалом характеризує дослідження сучасних авторів.

Метою cmammi $є$ аналіз становлення поняття соціальнопсихологічної зрілості, його виникнення, а також сучасних особливостей його розуміння. Це передбачає такі завдання: дослідження особливостей етапів формування даного поняття; виявлення поглядів різних дослідників, що здійснювали пошуки у цій галузі; аналіз сучасного розуміння поняття соціально-психологічної зрілості.

Виклад основного матеріалу. Визначення соціально-психологічної зрілості містить трактування соціальної та психологічної зрілості. Соціально-психологічна зрілість розглядається А. Журавльовим як зрілість особистості, яка виявляє себе у стосунках 3 іншими, 3 найближчим соціальним оточенням [Журавлев, 2007: c. 52]. Дослідження питання зрілості умовно було поділено М.Главатських на періоди [Главатских, 2015: c.95]. Упродовж першого періоду, - зазначає М. Главатських, - зрілість розглядається багатьма представниками наукових шкіл і створює загальний напрям досліджень. У більшості авторських публікацій «зрілість» трактували у контексті біологічного атрибута. Тут «зрілість» досягалася за допомогою спадкових передумов, що відповідно залежало від предків. Упродовж 30-40-pp ХХ ст. зрілість стала розглядатися як атрибут особистого розвитку (онтогенезу). Вона у Ж. Піаже пов’язувалася з розвитком певної функції психіки, яка дозволить розвинутись операціям формально-логічного мислення (індукція, дедукція). Тут зрілість тотожна поняттю дорослості та наступала приблизно у 12-15 років.

Упродовж другого періоду досліджень почали виникати суперечки між дослідниками стосовно показника «стабільності» життя як атрибуту зрілості. Дослідження А. Лідерса дозволили вважати, що сутність зрілості особистості виявляється у пошуку нею нових соціальних знань та навичок 


\section{Psychology}

як підгрунтя розвитку. Іншими словами, зрілість $\epsilon$ «опануванням» знання для власного росту, щоб змінити власні межі [Лидерс, 2012: с. 76]. Прикладом виходу за особистісні межі може слугувати прагнення до самопізнання себе у світі. Феномен особистісної зрілості доцільно висвітлити відповідно до гуманістичної парадигми, в якій саморозвиток особистості є аксіоматичним [Umena, 2008: c. 8]. Згідно 3 постулатами гуманістичного напрямку досліджень зрілість не $\epsilon$ стабільним утворенням, людині потрібно постійно змінюватися. Такий погляд гуманістичної психології зумовив переформатування розгляду зрілості з біологічного на соціальний [Главатских, 2015: с.95].

Наступний період розвитку думки про зрілість настав у середині 1960 pp. ХХ ст. У цей час поняття «особистісна зрілість» стає предметом дослідження науковців. Звісно найбільшим поштовхом були ідеї гуманістичної психології. Представники цього напрямку визначали зрілість як здатність бути цілісним, прагнути до розвитку, як втілення свого потенціалу. Виходить, що фізіологічна зрілість (віковий атрибут) перестає бути характеристикою особистісної зрілості, як зауважив А. Журавльов у своїй праці «Обгрунтування поняття соціально-психологічної зрілості» [Журавлев, 2007: c. 53]. У свою чергу М. Главатських зазначає, що відомі психологи Б. Ананьєв, А. Реан визнавали «зрілість» та «дорослість» не тотожними поняттями [Главатских, 2015: с. 95]. Відповідно до цих теорій «зрілість» почала розглядатися як досягнення найвищого рівня розвитку психіки. Засадничими для цього періоду стали напрацювання різних аспектів поняття зрілості: емоційного, інтелектуального, соціального, біологічного, морального. Дуже часто ці аспекти розумілися як синоніми. Було відсутне чітке розмежування між поняттями зрілості та компетентності, ефективності [Главатских, 2015: с. 95].

Відтак розвиток уявлень щодо поняття зрілості та виокремлення його різних складових спричинило перехід у нове русло досліджень. Упродовж цього нового періоду в ході значної кількості наукових розвідок аналізується велика кількість показників зрілої особи (інтегральний локус контролю, цілісність, відповідальність, емоційна стійкість тощо). Усі ці виявлені складові не особливо сприяли узгодженому розумінню соціальнопсихологічної зрілості особистості як цілісності. Авторські різночитання та перебільшення правильності власної позиції щодо запропонованих ними складових соціально-психологічної зрілості породжували поняттеву плутанину. Соціально-психологічна зрілість розглядається як якість системи, що забезпечує цілеспрямований прогресивний розвиток. Некласична психологія (1960-70-ті рр.) стає все більше схильною інтерпретувати людину як «незавершений проект». Тут розуміння соціально-психологічної зрілості ніби зводиться до попередніх етапів розвитку, регресує (Л. Колберг). Таким $є$ розуміння соціальнопсихологічної зрілості в теоріях Дж. Марсії, А. Ватермана, як зауважує А. Журавльов [Журавлев, 2007: с. 49]. За цих умов було створено поняття 
«псевдозрілість», яке стосувалося передовсім підлітків. Тут йдеться про те, що вік відповідає соціальній ролі, але вона не усвідомлюється та не переживається підлітком. Це спричиняє у нього відсутність належної поведінки.

Доволі важливою характеристикою цього періоду досліджень $є$ накопичення знань щодо вияву зрілості особистості у певних життєвих сферах. У закордонній психології напрацьовуються різні за змістом поняття: психологічна, психосоціальна, глобальна зрілість. Наприклад, поняття психосоціальної зрілості $є$ подібним 3 поняттям соціальнопсихологічної зрілості. Однак поняття психосоціальної зрілості майже не вживається у вітчизняній науці. Воно має більш об'ємний, узагальнений характер (містить соціальну, особистісну, групову, загальну тощо зрілість). Психосоціальна зрілість - це міра інтеграції особистості в соціальні групи, структури. Психосоціальна зрілість забезпечує повніше входження особистості в соціум. Натомість соціально-психологічна зрілість насамперед здобувається через налагодження міжособистісних взаємин, вияв просоціальних почуттів та поведінки (допомоги іншим, емпатії, дружби, любові тощо) [Журавлев, 2007: с. 51].

Накопичення значної кількості складових, які змістовно визначали поняття соціально-психологічної зрілості, породили кризу розуміння поняття. Ця криза була зумовлена дискусіями про основні чинники, які визначають це психологічне поняття. Вагомою спробою подолання цієї кризи стала спроба в холістичній теорії (Д. Магнусон) розгляду соціальнопсихологічної зрілості. У руслі холістичної теорії людина розглядалася як цілісна система, а дослідження її окремих аспектів не є доречним.

Під час третього періоду досліджень особистість постала одиницею комплексного аналізу [Журавлев, 2007: c. 50]. Значущим вкладом у цей етап, як вважає психолог А. Журавльов, здійснив своїми дослідженнями Б. Ананьєв. Дослідник створив новий напрямок дослідження поняття зрілості, а саме «глобальну зрілість». Таке трактування стало інтегральною характеристикою, яка поєднувала в собі наступні складові: індивідуальну (індивідуально-типологічні, соматичні особливості особи), особистісну (громадянські), сутнісну (складові елементи), об’єкт пізнання (розумова зрілість), працю (працездатність, працелюбність).

Важливих обрисів розуміння поняття зрілості надав К. Уайт. Автор розглядав набуття зрілості у взаємостосунках з іншими людьми. Зрілість виступає у дослідника як соціально-психологічна зрілість, що охоплює три рівні: его-центрування, орієнтацію на себе як виконавця соціальної ролі, індивідуалізацію зобов'язань (найвищий рівень). Автор додає до критеріїв соціально-психологічної зрілості не лише емпатію, децентрацію, а й рефлексію [Журавлев, 2007: с. 50].

А. Журавльов виокремив погляди вітчизняних дослідників зрілості, зокрема Л. Виготського, I. Кона. Л. Виготський, відповідно до розробленого закону культурно-історичного розвитку, трактував 


\section{Psychology}

особистісну зрілість як уже результат переведення зовнішнього у внутрішнє (інтеріоризація). Що ж до І. Кона, то він стверджує, що зрілість $\epsilon$ стадією соціального розвитку. 3 цього погляду особистість набуває здатності опановувати соціальними ролями, самостійними вчинками, приймання відповідальності за наслідки своєї соціальної поведінки, активну позицію у соціумі [Журавлев, 2007: c. 44]. Вищезазначеним дослідникам не вдалось повною мірою подолати кризу, яка пов'язана 3 нерозумінням основних чинників, які зумовлюють зрілість. Спробу змінити існуючий стан речей здійснив Е. Грінбергер. Дослідник розробив поняття, яке б змогло інтегрувати розрізнені категорії в одну загальну, такою категорією стала соціально-психологічна зрілість [Greenberger, 1974: c. 332]. Відповідно найбільш загальними критеріями, що були притаманні соціально-психологічній зрілості, $є$ активна соціальна позиція, соціальна відповідальність, самостійність. Е. Грінбергер виділяе критерії, які визначають дорослість як здатність до втілення власних і суспільних цілей. Це дозволяе цим критеріям набувати різної спрямованості стосовно суспільства (позитивна-негативна). Дослідник стверджує важливість якісної спрямованості на групу й особистість, вбачаючи зрілість саме у вкладі доброустрою соціуму і втіленні його цілей [Журавлев, 2007: c. 45]. Для кращого розуміння терміну соціальнопсихологічної зрілості дослідником було розділено загальну категорію зрілості на три базові компоненти:

- біологічний - зрілість виступає характеристикою індивіда, базуючись в першу чергу на періодах дозрівання організму, і втілюється в здатності вижити самостійно, а також успішно забезпечити відтворення собі подібних та забезпеченні їхнього виживання; відповідає віковій градації, внаслідок чого є динамічною; важливим атрибутом чого постає ускладнення організації процесів функціонування, особливо на останніх етапах зрілості; розвиток $є$ обов'язково поступовим і розпочинається на основі того, як завершився попередній етап, до прикладу внаслідок розвитку певної біологічної основи набуваються нові функції; перехід до наступного етапу розвитку передбачає успішне виконання попередніх етапів [Greenberger, 1974: c. 332];

- соціальний - зрілість у цьому контексті розглядається індивідуально, як характеристика, що набувається в процесі соціалізації та $€$ її кінцевим продуктом; орієнтована на майбутнє, повністю залежить від соціальної системи, в якій набувається; зокрема А. Інкелес 1968 р. у ході своїх досліджень процесу соціалізації виділив наступні аспекти: життєздатність економіки, довіра, механізми, що дозволяють бути системі витривалою; модель соціальної зрілості передбачає здатність ii носія успішно функціонувати, займатися певною суспільно корисною діяльністю та об'єднуватися із собі подібними, бути носієм системи та іiі представником [Greenberger, 1974: c. 332]; 
• психологічний - постає персональним продуктом процесу дозрівання, розвитку і функціонування певних рис і передбачає інтеграцію: соціальної включеності (соціалізацію) та здоров'я розуму (біологічні передумови) для успішного набуття зрілості, що по суті робить його об'єднуючим компонентом [Greenberger, 1974: c. 332].

Відтак біологічна модель зрілості $\epsilon$ скерованою на виживання організму. Соціальна модель зорієнтована на збагачення, розбудову та виживання соціальної системи, в якій дозріває особа. Психологічна зрілість акцентує увагу на остаточному персональному продукті процесу дозрівання. Е. Грінбергер об`єднує ці складові та виводить нову інтегральну модель соціально-психологічної зрілості [Greenberger, 1974: c. 333]. Е. Грінбергер побудував концепцію, основними позиціями якої є: індивідуальна адекватність (ефективне функціонування), інтерперсональна адекватність (міжособистісні взаємини), соціальна адекватність (сприяння соціальній єдності) [Greenberger, 1974: c. 350]. До загальних показників соціально-психологічної зрілості Е. Грінбергер відносить: автономність особи, соціальну відповідальність за вчинки, активну соціальну позицію щодо ресоціалізації, опанування соціальних ролей, рефлексії, емпатії. Зріла соціально-психологічно особа $\epsilon$ соціально адаптованою особою, яка засвоїла норми взаємин із соціальними структурами суспільства та орієнтована на досягнення власних цілей, тобто індивідуалізована [Журавлев, 2007: с. 53].

Запропонована у 1974 p. Е. Грінбергером модель було згодом розширено Л. Стернбергом у 1990 р. Дослідник на основі своїх пошуків зазначив, що важливим для набуття соціально-психологічної зрілості є такі додаткові складові: темперамент (контроль імпульсів), перспектива (здатність зауважувати критичні думки, точку зору інших людей, щоб побачити перспективу, наслідки), відповідальність (здатність відповідати за свою поведінку та протистояти неконструктивним впливам інших) [Khatibi, 2016: c. 58].

Відтак найбільш повним та об’єднуючим є розуміння поняття соціально-психологічної зрілості як інтегрального. Соціально-психологічна зрілість особистості тут є властивістю соціального суб'єкта, який готовий до самореалізації шляхом перетворення соціальної дійсності, просоціальної поведінки та взаємодії зі своїм довкіллям, людьми. Поняття об'єднує наступні аспекти: особистісний (власний розвиток), соціальний (просоціальну поведінку), динамічний (постійне духовне збагачення, вироблення соціальних навичок), контекстний (культурно-історичні умови розвитку). Дане розуміння поняття соціально-психологічної зрілості особистості містить двоєдиність аспектів особистості: соціальну й індивідуальну [Погорова, 2016: с. 54].

Соціально-психологічна зрілість постає як певна об'єднувальна ланка двох попередніх напрямків досліджень зрілості: соціальної та 


\section{Psychology}

індивідуально-орієнтованої. Ц Це відкриває перспективу подальшого дослідження соціально-психологічної зрілості в науці. Згідно з сучасними поглядами соціально-психологічна зрілість виявляється у здатності людини володіти системою просоціальної ціннісної зорієнтованості, що дозволяє їй розвивати себе та суспільство, уникати делінквентної, залежної поведінки. До соціально-психологічної зрілості відносять здатність особистості активно виявляти свою громадянську позицію. Ця складова перетворює людину в дієвого суб'єкта суспільства, здатного змінювати себе та світ [Погорова, 2016: с. 53].

Соціально-психологічна зрілість розглядається закордонними дослідниками (Р. Погорова, О. Тетухіна та ін.) як складна динамічна, особистісна структура, що має вияв у чотирьох сферах: потребовомотиваційний (самоставлення), афектна (емоції), когнітивна (саморозуміння), регулятивно-вольова (саморегуляція). Доречно звернутися також до певних проблемних методичних аспектів дослідження соціально-психологічної зрілості, зокрема їі дослідження за допомогою різних психологічних методик. Існують емпіричні проблеми дослідження зрілості, оскільки в межах різних соціокультурних шкіл поняття має свої особливості, тому методики відображають цю специфіку. Можна погодитися 3 думкою А. Журавльова про те, що існує «неперервність» та «перервність» розвитку показників зрілості, які не мають чітких критеріїв [Журавлев, 2007: c. 45]. Наступною проблемою є нерівномірність у досягненні зрілості через призму іiі кожної окремої складової. Зокрема немає чіткості розуміння та інтерпретації «загальної зрілості», наприклад, якщо певні складові (компоненти) перейдуть межу зрілості. Гетерохронність доповнюється також іншими труднощами - це нелінійність зростання зрілості (у кожної особи своя), особистісні кризи та їхній вплив на зрілість, реверсивність розвитку тощо.

Висновки. Здійснений аналіз дозволив показати, що поняття соціально-психологічної зрілості $€$ інтегральним. Дослідники виокремлюють щонайменше три складові елементи інтегрального поняття: біологічний, соціальний, психологічний. Саме в єдності трьох компонентів соціально-психологічна зрілість як поняття охоплює різні грані взаємодії особистості та суспільства. Звісно, поняття вміщує в собі також інший досвід напрацювань: соціологічний, культурологічний тощо. Погляди закордонних та вітчизняних науковців відображали тенденції загального етапу розвитку, на якому перебувала психологічна наука. Відтак соціально-психологічна зрілість вважалася спочатку лише характеристикою організму та залежала від набуття людиною певного віку. Прикладом цього слугувала вікова періодизація Е. Еріксона. На наступному етапі розвитку (60-70 pp. ХХ ст.) соціально-психологічну зрілість уже поділяли окремо на біологічну, соціальну, психологічну. На третьому етапі відбулося формування знань про соціальнопсихологічну зрілість як інтегральне поняття. 
Важливим $є$ сучасне розуміння того, що зрілість не приходить автоматично 3 настанням певного віку людини. Ії необхідно постійно формувати, зауважувати умови соціалізації, навчання та виховання. Важливими компонентами соціально-психологічної зрілості $\epsilon$ автономність, соціальна відповідальність за вчинки, просоціальна поведінка (допомога іншому), активна соціальна позиція в ресоціалізації, опанування соціальними ролями, рефлексія, емпатія. Ці компоненти укладають соціально-психологічну зрілість як складну динамічну особистісну структуру та виявляються у чотирьох сферах: потребовомотиваційній (самоставлення), афектній (емоціi), когнітивній (саморозуміння), регулятивно-вольовій (саморегуляція). Детальне розроблення поняття соціально-психологічної зрілості в контексті зазначених сфер є перспективним завданням подальшого дослідження.

\section{ЛІТЕРАТУРА}

Главатских, 2015 - Главатских М. М. К проблеме изучения понятия социально-психологической зрелости личности. Вестник Оренбургского государственного университета. 2015. № 7 (182). С. 94-97.

Журавлев, 2007 - Журавлев А. Л. Социально-психологичиская зрелость: обоснования понятия. Психологичкский журнал. 2007. Т. 28. № 2. С. 44-54.

Погорова, 2016 - Погорова Р. И. К вопросу о смысловом содержании понятия «социальнопсихологическая зрелость». Высшее образование сегодня. 2016. № 5. С. 53-55.

Лидерс, 2012 - Лидерс А.Г., Буровихина И. А. Социальная ситуация развития как условие формирования образа мира в отрочестве. Национальный психологический журнал. 2012. №. 2. C. $75-81$.

Шmеnа, 2008 - Штепа О. С. Особистісна зрілість: Модель. Опитувальник. Тренінг: монографія. Львів : Видавничий центр ЛНУ імені Івана Франка, 2008. 210 с.

Greenberger, 1974 - Greenberger E., Sørensen A. B. Toward a concept of psychosocial maturity. Journal of Youth and Adolescence. 1974. Vol 3. № 4. P. 329-358.

Khatibi, 2016 - Khatibi M., Razieh S. Greenberger Psychosocial Maturity Model: A Brief Review. Journal of Educational and Management Studies; J. Educ. Manage. Stud. 2016. June 25. 6 (2). P. 57-61.

\section{REFERENCES}

Hlavatskykh, 2015 - Hlavatskykh M. M. K probleme yzuchenyia poniatyia sotsyalnopsykholohycheskoi zrelosty lychnosty. Vestnyk Orenburhskoho hosudarstvennoho unyversyteta. 2015. № 7 (182). S. 94-97.

Zhuravlev, 2007 - Zhuravlev A. L. Sotsyalno-psykholohychyskaia zrelost: obosnovanyia poniatyia. Psykholohychkskyi zhurnal. 2007. T. 28. № 2., S. 44-54.

Pohorova, 2016 - Pohorova R. Y. K voprosu o smyslovom soderzhanyy poniatyia «sotsyalnopsykholohycheskaia zrelost». Visshee obrazovanye sehodnia. 2016. № 5. S. 53-55.

Lyders, 2012 - Lyders A. H., Burovykhyna Y. A. Sotsyalnaia sytuatsyia razvytyia kak uslovye formyrovanyia obraza myra v otrochestve. Natsyonalnbli psykholohycheskyi zhurnal. 2012. №. 2. S. $75-81$.

Shtepa, 2008 - Shtepa O. S. Osobystisna zrilist: Model. Opytuvalnyk. Treninh. Monohrafiia. Lviv : Vydavnychyi tsentr LNU imeni Ivana Franka, 2008. 210 s. 